ISSN: 2224-0616

Int. J . Agril. Res. Innov. \& Tech. 8 (1): 1-6, June, 2018

Available online at http:// www.ijarit.webs.com

\title{
COMPARATIVE EFFECTS OF J ATROPHA SEEDCAKE, CHICKEN AND KRAAL MANURES ON SELECTED SOIL PROPERTIES, GROWTH AND YIELD OF TOMATO (Lycopersicon esculentum)
}

\author{
W. Mambo'*, M. Mataa ${ }^{2}$ and B.H. Chishala ${ }^{3}$
}

Received 30 November 2017, Revised 3 June 2018, Accepted 26 June 2018, Published online 30 June 2018

\begin{abstract}
A field trial was conducted to evaluate the comparative effects of jatropha seedcake, chicken and kraal manures on selected soil properties, growth and yield of tomato in Zambia during the cropping season of 2012-13. A Randomized Complete Block Design (RCBD) with four replicates and six treatments, namely- jatropha seedcake (5.0 t ha-1), chicken manure (5.0 t ha-1), kraal manure (5.0 t ha-1), jatropha seedcake $\left(2.5 \mathrm{t} \mathrm{ha}^{-1}\right)+$ chicken manure (2.5 $\left.\mathrm{t} \mathrm{ha}^{-1}\right)$, jatropha seedcake $\left(2.5 \mathrm{t} \mathrm{ha}^{-1}\right)+$ kraal manure $\left(2.5 \mathrm{t} \mathrm{ha}^{-1}\right)$ and control $\left(0.0 \mathrm{t} \mathrm{ha}^{-1}\right)$ was used. Soil total $\mathrm{N}, \mathrm{P}, \mathrm{K}, \mathrm{Ca}, \mathrm{Mg}$, SOM, soil pH, bulk density, plant height, number of branches, number of fruits plant -1 , and mean fruit weight effects were subsequently monitored. Organic manures significantly increased total N, available P, exchangeable K, Ca, Mg, SOM, soil pH, plant height, number of branches, number of fruits, mean fruit weight and yield of tomato compared to the control. Organic manures also significantly reduced soil bulk density compared to the control. Among the organic amendments treated alone, jatropha seedcake gave the highest yield of $28.62 \mathrm{t} \mathrm{ha}^{-1}$ compared to chicken manure (28.20 t ha-1) and kraal manure (27.50 t ha-1). Maximum yield benefits came from a mixture of jatropha seedcake + chicken manure (29.60 t ha-1)and jatropha seedcake + kraal manure (29.00 tha1) which could have been due to balanced proportions of major nutrients required for tomato growth. Jatropha seedcake mostly performed favourably the same or better than chicken and kraal manures in many aspects.
\end{abstract}

Keywords: J atropha curcas, Phorbol Ester, Bio-fuel, Bio-waste, Organic Manure

${ }^{1}$ Graduate Student, Department of Agriculture, Ministry of Agriculture, P.O. Box 740024, Nchelenge, Zambia.

${ }^{2}$ Department of Plant Sciences, School of Agricultural Sciences, University of Zambia, Lusaka, Zambia, P.O. Box 32379, Lusaka, Zambia.

${ }^{3}$ Department of Soil Sciences, School of Agricultural Sciences, University of Zambia, P.O. Box 32379, Lusaka, Zambia.

*Corresponding author's email: wagemambo@yahoo.com (Wages Mambo)

\section{Introduction}

Tomato, Lycopersicon esculentum is an important crop grown throughout the country and all year round for their fruits (Mingochi and Luchen, 2000). The low yields would be indicative of a tomato crop grown in unfavourable growing conditions that attract high level of management practices, frequent pest and disease control. Hence, the ability of a farmer to manipulate their production environment, such as application of both organic and inorganic fertilizers boosts crop productivity and avoids supply shocks (Mwiinga, 2009).

Intensive and widespread use of inorganic fertilizers and pesticides adversely affects the soil environment, leading to decreased crop productivity and production of potentially harmful food, unsafe for human consumption. These unintended harmful effects and the energy intensive processes involved in the production of inorganic fertilizers have resulted in several research initiatives for developing organic fertilizer alternatives (Chaturvedi and Kumar, 2012).
Processing of bio-fuel from jatropha in Zambia had significantly increased over the past two decades and this resulted in the production of large quantities of jatropha seedcake but this has since reduced in recent years. However, jatropha seedcake will possibly increase in the near future since the Zambian Government has embraced this programme and more NGOs and private companies are likely to come on board. Seed cake resulting from jatropha is not suitable for use as a livestock feed (Martínez-Herrera et al., 2006; Li et al., 2010) and not environmentally friendly because of the presence of toxic component, phorbol ester. This poses the challenge of safe disposal of the seedcake. In Zambia, manures used by farmers include kraal, chicken and green manures, and composted crop/plant residues, which tend to be of very low quality with limited contribution to crop yields. The variability in the nutrient content status of different organic manures would necessitate in certain instances to mix individual organic manures in order to improve their nutrient status and efficacy. These 
manures are scarce and when available their volumes are insufficient to meet the demand. The large amount of de-oiled jatropha seedcake produced by oil-extraction process is valuable as organic manure due to its high nitrogen content (up to $6.48 \%$ ) and can be used to maintain fertility of soil (Singh et al., 1996; Chaturvedi et al., 2008a; Chaturvedi et al., 2010).

Several types of bio-waste like jatropha, neem, salvadora, maduca and pongamia have shown potential of being used as fertilizers and these not only improve the organic content of soil but also act as effective insecticides and fungicides (Chaturvedi et al., 2008a; Chaturvedi et al., 2008b). However, the extent to which jatropha seedcake could affect the soil properties, growth and yield of tomato has not received much research attention in Zambia. The little data available, however, indicate that the residue oil cake generated during oil extraction of bio-diesel production can be used as fertilizer (CanoAsseleih et al., 1989; J ayasingh, 2003), but does not provide information on its effects on the soil properties, growth and yield of tomato when used as organic manure. The objectives were to evaluate the effects of jatropha seedcake, chicken and kraal manures on selected soil properties, growth and yield of tomato.

\section{Materials and Methods}

\section{Manures and plant materials}

Jatropha seedcake was sourced from Southern Bio-power in Kalundu, Lusaka while chicken and kraal manures were obtained from the Field Station, School of Agricultural Sciences at the University of Zambia (UNZA) tomato 'Tengeru' seedlings were purchased from a private nursery at three weeks old, about $12 \mathrm{~cm}$ tall and with high vigour and had no signs of pests and diseases. Tengeru is indeterminate, with about 105 days to maturity and resistant to early and late blight, with a long shelf life of 2-3 weeks at room temperature.

\section{Experimental site location}

Field experiment was conducted at the Zambia Agricultural Technology Development Centre, $15^{\circ}$ $24^{\prime} 52^{\prime \prime} \mathrm{S}$ and $29^{\circ} 05^{\prime} 18^{\prime \prime} \mathrm{E}$ in Chongwe district,
Zambia. The soils are Loamy sand and are classified as Lixisols (Ministry of Agriculture, 1991).

\section{Experimental design and treatments}

The experiment was laid out in a Randomized Complete Block Design (RCBD) with four replicates and six treatments comprising jatropha seedcake (5.0 t ha-1), chicken manure (5.0 t ha-1), kraal manure (5.0 t ha-1), jatropha seedcake (2.5 t ha-1) + Chicken manure (2.5 t ha1), jatropha seedcake (2.5 t ha-1) + kraal manure (2.5 t ha $\left.^{-1}\right)$ and the untreated control.

\section{Determination of physical property (bulk density) from core method}

The soil bulk density was determined prior to the application of treatments and at the end of the field experiment fourteen weeks after treatments application from oven-dried undistributed core samples collected to the depth of $0-10 \mathrm{~cm}$ by core method as described by Stolte et al. (1992).

\section{Soil sampling and chemical analysis}

Twenty-four soil samples $(0-20 \mathrm{~cm}$ depth) were randomly taken at the experimental site prior to the application of treatments and another set of twenty-four soil samples were taken in specified treated planting stations at the end of the experiment. Purposive sampling method was used (de Gruijter, 2002). Each set of samples was bulked, air-dried, sieved to pass through a $2 \mathrm{~mm}$ mesh and analysed for chemical properties. Total $\mathrm{N}$ was determined by the macro-kjeldahl method (Bremner and Mulvancy, 1982), available P was extracted by the Bray-1 method and determined colorimetrically (Bray and Kurtz, 1945). Exchangeable $\mathrm{K}, \mathrm{Ca}$, and $\mathrm{Mg}$, were extracted with 1.0 $\mathrm{N} \mathrm{NH}_{4} \mathrm{OAc}$ using a soil: solution volume ratio of 1:10. The $K$ in the extract was read using a flame emission photometer, while $\mathrm{Ca}$ and $\mathrm{Mg}$ were determined by Atomic Absorption Spectrophotometer (AAS) (Perkin-Elmer, 1994). Organic carbon content was determined by Walkley-Black dichromate oxidation method (Walkley and Black, 1934) and the $\mathrm{pH}$ was determined by using a soil/ organic manure water medium at a ratio of 1:2.5 using a digital electronic $\mathrm{pH}$ meter.

Table 1. Characterization of the soil used in the experiment in the top soil (0-20 cm depth) at the experimental site in 2012-13 cropping season.

\begin{tabular}{lc}
\hline Soil property & Soil sample value \\
\hline \%TN & 0.11 \\
$\mathrm{mg} \mathrm{P} \mathrm{kg}$ & 9.40 \\
$\mathrm{cmol} \mathrm{K} \mathrm{kg}^{-1}$ & 0.50 \\
$\mathrm{cmol} \mathrm{Mg} \mathrm{kg}^{-1}$ & 0.88 \\
$\mathrm{cmol} \mathrm{Ca} \mathrm{kg}$ & 5.93 \\
\% C & 1.37 \\
$\mathrm{C} / \mathrm{N}$ ratio & 12.45 \\
$\mathrm{pH}$ & 6.56 \\
Bulky density $\left(\mathrm{g} \mathrm{cm}^{-3}\right)$ & 1.62 \\
\hline
\end{tabular}




\section{Manure application}

Manures were placed in specified planting stations of $15 \mathrm{~cm} \times 15 \mathrm{~cm} \times 35 \mathrm{~cm}$ dimensions. These were then covered with a thin layer of soil, with each receiving $150 \mathrm{~g}$ of organic manure equivalent to an application rate of $5.0 \mathrm{t} \mathrm{ha}^{-1}$ one month before transplanting tomato seedlings. 0.5 litres of water was applied at an interval of every three days for one month to allow decomposition of the organic manures. Replication of 10 planting stations for each of jatropha seedcake, chicken manure and kraal manure samples for laboratory chemical analysis was also conducted. After a month, partially decomposed organic manures from 10 replicated planting stations were then subjected to chemical analysis.

\section{Planting}

Each plot had a dimension of $1.2 \mathrm{~m} \mathrm{x} 3.5 \mathrm{~m}$ with planting stations spaced at $60 \mathrm{~cm} \times 50 \mathrm{~cm}$, giving twenty-four plants per plot. Transplanting of seedlings was done on 30 November, 2012 in the afternoon at three (3) weeks old with plant height of approximately $12 \mathrm{~cm}$. The crop was rain fed and therefore, irrigation was only done during times of partial droughts. Staking of plants was done at two weeks after transplanting.

\section{Plant protection}

Routine sprays of carabyl against aphids (Aulacorthum solani), Tik tok (dicofol) against red spider mites (Tetranychus spp.) and Dithane M45 against fungal diseases such as early blight (Alternaria solani) and late blight (Phytophthora infestans) were carried out. Hand hoe weeding was carried out 3 times throughout the growing period.

Table 2. Characterization of jatropha seedcake, chicken manure and kraal manure used in the experiment.

\begin{tabular}{lccc}
\hline Property & Jatropha seedcake & Chicken manure & Kraal manure \\
\hline $\mathrm{N}(\%)$ & 3.60 & 2.82 & 2.13 \\
$\mathrm{P}(\%)$ & 0.89 & 0.80 & 0.76 \\
$\mathrm{~K}(\%)$ & 2.20 & 2.49 & 2.06 \\
$\mathrm{Mg}(\%)$ & 0.56 & 0.51 & 0.49 \\
$\mathrm{Ca}(\%)$ & 1.53 & 1.34 & 1.08 \\
OC $(\%)$ & 21.06 & 1.54 & 1.74 \\
$\mathrm{C} / \mathrm{N}$ ratio & 5.85 & 0.55 & 0.82 \\
pH & 7.90 & 8.00 & 7.60 \\
\hline
\end{tabular}

There was also significant difference between treatments on the effect of total N. Jatropha seedcake recorded higher increase in total $\mathrm{N}$ than chicken manure or kraal manure. However, a mixture of jatropha seedcake + chicken manure significantly increased the other treatments. This was attributed to the levels of nitrogen in jatropha seedcake and chicken manure. This agrees with Ahmad et al. (2007), who indicated

\section{Harvesting}

Harvesting of ripened tomatoes was done by hand picking, counted and weighed for each plant every three days between 12-14 weeks after transplanting.

\section{Data analysis}

Twelve plant stands were selected as datum plants. The plant height above ground was measured using a measuring tape. The number of branches from the main vine and the number of fruits per plant were physically counted and recorded. Fruit weight was determined using a weighing balance. The fruit yield ( $\left.\mathrm{t} \mathrm{ha}^{-1}\right)$ was then determined. The collected data were subjected to standard statistical analysis of variance using GENSTAT statistical package (17th Edition) and then mean values were compared using the Least Significant Difference (LSD) at P $=0.05$ (Little and Hills, 1978).

\section{Results and Discussion}

\section{Soil chemical properties}

The data indicated that the soils were slightly acidic, low in total $\mathrm{N}$, soil organic matter (SOM), available $\mathrm{P}$, exchangeable $\mathrm{K}$, Ca and Mg. Table 2 shows characterization of organic manure used in the experiment. Table 3 shows the influence of organic amendments on some selected soil chemical properties. Plots treated with organic amendments had significantly $(\mathrm{P}=0.05)$ higher total $\mathrm{N}$, available $\mathrm{P}$, exchangeable $\mathrm{K}, \mathrm{Ca}$ and $\mathrm{Mg}$, soil organic matter and $\mathrm{pH}$ compared to the untreated control. that the type of organic material and its quality influence the soil characteristics and nutrient supply to the crops variably. There was a significant increase in the available $\mathrm{P}$ with the application of organic amendments compared to the control. However, a mixture of jatropha seedcake with either chicken manure or kraal manure gave higher increase of $\mathrm{P}$ compared to jatropha seedcake applied alone. 
Table 3. Effects of different organic amendments on selected soil properties 14 weeks after transplanting tomato.

\begin{tabular}{|c|c|c|c|c|c|c|c|c|}
\hline Treatment & $\% \mathrm{TN}$ & $\underset{\mathrm{kg}^{-1}}{\operatorname{mgP}}$ & $\underset{\mathrm{kg}^{-1}}{\mathrm{Cmol} \mathrm{K}}$ & $\begin{array}{c}\mathrm{Cmol} \mathrm{Ca}^{1} \\
\mathrm{~kg}^{1}\end{array}$ & $\underset{\mathrm{kg}^{-1}}{\mathrm{Cmol} \mathrm{Mg}}$ & \% SOM & $\mathrm{pH}$ & $\begin{array}{c}\text { Bulk } \\
\text { density }\end{array}$ \\
\hline Chicken manure & $1.84 \mathrm{C}$ & $24.89 \mathrm{c}$ & $0.56 c$ & $17.95 \mathrm{c}$ & $6.78 c$ & $8.30 \mathrm{e}$ & $7.30 \mathrm{a}$ & $1.43 \mathrm{~b}$ \\
\hline Kraal manure & $1.59 \mathrm{~d}$ & $23.95 c$ & $0.57 \mathrm{c}$ & $19.80 \mathrm{~b}$ & $6.60 \mathrm{bc}$ & $10.90 \mathrm{c}$ & $7.29 \mathrm{ab}$ & $1.37 \mathrm{c}$ \\
\hline Jatropha seedcake & $1.95 \mathrm{~b}$ & $26.97 \mathrm{bc}$ & $0.60 \mathrm{~b}$ & $18.10 \mathrm{c}$ & $6.98 \mathrm{bc}$ & $13.70 \mathrm{a}$ & $7.25 \mathrm{c}$ & $1.30 \mathrm{~d}$ \\
\hline $\begin{array}{l}\text { J atropha seedcake + } \\
\text { chicken manure }\end{array}$ & $2.25 \mathrm{a}$ & $34.40 \mathrm{a}$ & $0.70 \mathrm{a}$ & $21.60 a$ & $7.05 \mathrm{ab}$ & $10.30 \mathrm{~d}$ & 7.27abc & $1.41 \mathrm{~b}$ \\
\hline $\begin{array}{l}\text { Jatropha seedcake + } \\
\text { Kraal manure }\end{array}$ & $2.00 \mathrm{~b}$ & $29.20 \mathrm{~b}$ & $0.70 \mathrm{a}$ & $21.20 \mathrm{a}$ & $7.38 \mathrm{a}$ & $12.30 \mathrm{~b}$ & 7.26bc & $1.34 \mathrm{c}$ \\
\hline Control (untreated) & $0.95 e$ & $6.75 d$ & $0.20 \mathrm{~d}$ & $6.39 d$ & $0.72 d$ & $1.50 \mathrm{f}$ & $6.56 \mathrm{~d}$ & $1.60 \mathrm{a}$ \\
\hline Mean & 1.76 & 24.36 & 0.56 & 17.51 & 5.92 & 9.5 & 7.16 & 1.41 \\
\hline L.S.D. & 0.09 & 3.11 & 0.02 & 0.86 & 0.35 & 0.25 & 0.04 & 0.04 \\
\hline
\end{tabular}

Means followed by the same letter(s) in the same column are not significantly different from each other at $\mathrm{p}=0.05$ level.

This also implied that the application of $\mathrm{P}$ to the soil from a mixture of jatropha seedcake and resultant release of $\mathrm{P}$ increased the activity of soil microorganisms (Arancon et al., 2006). Marinari et al. (2000) showed similar increases in soil $\mathrm{P}$ after application of organic amendments. The level of potassium $(\mathrm{K})$ was significantly increased by the application of organic manures compared to the control. There was no significant difference in the level of potassium among jatropha seedcake, chicken manure and kraal manure treated plots. The potassium content in jatropha seedcake was found to be $2.2 \%$, chicken manure was $2.49 \%$ while kraal manure was $2.06 \%$. These percentages are relatively the same and this was the more reason no significant difference was recorded amongst jatropha seedcake, chicken manure and kraal manure. There was no significant difference between the mixture of jatropha seedcake + chicken manure and jatropha seedcake + kraal manure but the mixtures significantly influenced potassium content compared jatropha seedcake, chicken manure and kraal manure treated alone. This observation could have been that mixtures had additive effects on $\mathrm{K}$ resulting from the two organic manures in the composite manure. The increase of soil organic matter resulted in decrease $\mathrm{K}$ fixation and subsequent increase $\mathrm{K}$ availability (Olk and Cassman, 1993). Application of organic manure significantly increased both $\mathrm{Ca}$ and $\mathrm{Mg}$ compared to the control. The increase of soluble calcium content with the addition of jatropha seedcake and other treatments to soil was caused by high calcium content of the organic amendments. However plots treated with mixtures of jatropha seedcake + chicken manure or jatropha seedcake+ kraal manure significantly increased calcium levels compared to jatropha seedcake, chicken manure and kraal manure applied alone. This shows that mixing jatropha seedcake with either chicken manure or kraal manure led to improvement in the nutrition status of the mixture. The high proportion of calcium levels in organically treated plots also tended to have high $\mathrm{pH}$ values since calcium has neutralizing properties and therefore to raise the $\mathrm{pH}$ of acid soils. Magnesium levels were significantly influenced with the application of organic manures compared to the control. However, no significant difference was recorded amongst the treatments that were applied alone. This was so because the magnesium content amongst the individual organic manures was marginal e.g. jatropha seedcake had $0.56 \%$, chicken manure had $0.51 \%$ and kraal manure had $0.49 \%$. There was also no significant difference recorded between the two mixtures. A mixture of jatropha seedcake + kraal manure influenced the highest increase in Mg. This was because of the individual manures in the mixtures had almost the same proportion of magnesium. The application of organic amendments significantly increased organic matter compared to the control. Jatropha seedcake had significantly increased organic matter compared to the other individual organic amendments. A mixture of jatropha seedcake with either chicken manure or kraal manure treated plots recorded lower levels of organic matter compared to jatropha seedcake applied alone. This could have been due to the lower levels of organic matter content of the chicken manure $\left(2.5 \mathrm{t} \mathrm{ha}^{-1}\right)$ or kraal manure $(2.5 \mathrm{t}$ ha $^{-1}$ ) added compared to the equivalent amount of jatropha seedcake (2.5 $\mathrm{t}$ ha-1) $^{-1}$ replaced and therefore reducing the overall organic matter content of the blend. Generally, organic manures have higher organic matter content and therefore are good sources of replenishment of organic matter in the soil for supplying microorganisms with $\mathrm{N}$ vital for decomposition activities. The organic matter influence on soil $\mathrm{pH}$ was depended on both the initial $\mathrm{pH}$ of the organic manure and the soil $\mathrm{pH}$.

The increase in soil $\mathrm{pH}$ could be due to the higher $\mathrm{pH}$ value of the chicken manure, kraal manure and jatropha seedcake were $\mathrm{pH}$ of $8.8,8.2$ and 7.9 , respectively in relation to the soil $\mathrm{pH}$ of 6.56 . This increase is not considered dangerous to soil quality because the values remained close to neutrality. The sensitivity of soil $\mathrm{pH}$ to the organic amendments was partly due to the low buffering capacity (Neilsen et al., 1998). The higher $\mathrm{pH}$ of organically amended plots compared to the control also might partially be due to the calcium supplied to the soil by organic manures, which has neutralizing effect. The highest increase in $\mathrm{pH}$ was recorded by chicken manure followed by kraal manure. These results are supported by the fact that the initial $\mathrm{pH}$ of the organic manure affects the extent to which they influence the final $\mathrm{pH}$ of the soil. 


\section{Soil physical property (bulk density)}

Organic manure application significantly influenced soil bulk density compared to the control. Jatropha seedcake treated plots had the highest reduction effect on bulk density compared to other amendments and this could be attributed to the high proportion of organic matter content for jatropha seedcake $(21.06 \%)$ in relation to chicken manure $(1.54 \%)$ and kraal manure (1.74\%). The decrease in soil bulk density could make considerable difference in the root growth and therefore, overall growth of the plant. These findings confirmed the earlier reports of Lombin et al. (1991); Mbah et al. (2004) that application of organic manures improves several soil physical properties such as soil bulk density.

\section{Effect of organic manure amendments on growth parameters and yield}

Application of organic manures significantly increased plant height, number of branches and fruits per plant, fruit weight and yield of tomato compared to the control as shown in Table 4. Different types of organic manures had varying effects on the vegetative growth and yield of tomato. The highest plant height of $107 \mathrm{~cm}$ was recorded by jatropha seedcake and chicken manure, which was significantly different from kraal manure but did not show any significant difference with jatropha seedcake+ chicken manure and jatropha seedcake+kraal manure.

Table 4. Results showing the effect of different organic amendments on growth parameters and yield of tomato.

\begin{tabular}{lccccc}
\hline Treatment & $\begin{array}{c}\text { Plant height } \\
(\mathrm{cm})\end{array}$ & $\begin{array}{c}\text { Branches } \\
\text { plant }^{-1}\end{array}$ & $\begin{array}{c}\text { Fruits } \\
\text { plant }^{-1}\end{array}$ & $\begin{array}{c}\text { Fruit weight } \\
(\mathrm{g})\end{array}$ & $\begin{array}{c}\text { Yield } \\
\left(\mathrm{t} \mathrm{ha}^{-1}\right)\end{array}$ \\
\hline Chicken manure & $107.0 \mathrm{a}$ & $11.0 \mathrm{a}$ & $25.0 \mathrm{c}$ & $112.0 \mathrm{a}$ & $28.20 \mathrm{c}$ \\
Kraal manure & $104.0 \mathrm{~b}$ & $10.0 \mathrm{a}$ & $27.0 \mathrm{~b}$ & $103.6 \mathrm{~b}$ & $27.50 \mathrm{~d}$ \\
Jatropha seedcake & $107.0 \mathrm{a}$ & $11.0 \mathrm{a}$ & $25.0 \mathrm{c}$ & $113.6 \mathrm{a}$ & $28.62 \mathrm{bc}$ \\
Jatropha seedcake + Chicken manure & $105.0 \mathrm{ab}$ & $10.0 \mathrm{a}$ & $29.0 \mathrm{a}$ & $102.0 \mathrm{~b}$ & $29.60 \mathrm{a}$ \\
Jatropha seedcake + Kraal manure & $105.0 \mathrm{ab}$ & $10.0 \mathrm{a}$ & $29.0 \mathrm{a}$ & $100 . .1 \mathrm{~b}$ & $29.00 \mathrm{ab}$ \\
Control (untreated) & $62.0 \mathrm{c}$ & $7.0 \mathrm{~b}$ & $20.0 \mathrm{~d}$ & $65.0 \mathrm{c}$ & $13.00 \mathrm{e}$ \\
Mean & 98.0 & 9.8 & 26.00 & 99.3 & 25.99 \\
L.S.D. & 2.7 & 1.2 & 1.5 & 3.6 & 0.61 \\
\hline
\end{tabular}

Means followed by the sameletter(s) in the same column are not significantly different from each other at $\mathrm{p}=0.05$ level.

Application of organic manures significantly increased plant height, number of branches and fruits plant ${ }^{-1}$, fruit weight and yield of tomato compared to the control as shown in Table 4. Different types of organic manures had varying effects on the vegetative growth and yield of tomato. The highest plant height of $107 \mathrm{~cm}$ was recorded by jatropha seedcake and chicken manure, which was significantly different from kraal manure but did not show any significant difference with jatropha seedcake + chicken manure and jatropha seedcake + kraal manure. However, no significant influence was recorded in the number of branches amongst the five organic manures. This observation could be that all the organic manure treated plots had almost the proportion of the nutrients required to support growth of branches. A mixture of jatropha seedcake with its associations with either chicken or kraal manure recorded the same number of fruits of 29 plant $^{-1}$ while jatropha seedcake and chicken manure also recorded the same number of fruits of 25. The positive effect of organic amendments added to the soil also may be attributed to stimulating the activity of bacteria, which promote the release availability of N, P, K and the other nutrients in the soil, and enhances nutrients absorption by tomato roots (Bertand and Cleyetmarel, 2008). Magnesium is involved in chlorophyll synthesis, which in turn increases the rate of photosynthesis. Application of organic manures thus would have helped in the plant metabolic activity through the supply of such important macronutrient in the early vigorous growth (Anburani and Manivannan, 2002). While higher yield was obtained by jatropha seedcake among the treatments applied alone with $28.62 \mathrm{t}$ ha- $^{-1}$, a mixture of jatropha + chicken recorded the highest yield of $29.6 \mathrm{t} \mathrm{ha}^{-1}$, followed by jatropha + kraal manure with $29.00 \mathrm{t} \mathrm{ha}^{-1}$. The high yield recorded by the mixture of jatropha + chicken might be because of the presence of N, P and K that are essential macronutrients for plant growth. The untreated control had the least N, P, $\mathrm{K}$, $\mathrm{Ca}$, and $\mathrm{Mg}$ and soil organic matter. The lowest nutrients recorded by the control experiment might be the reason why the plant parameters observed such as plant height, number of branches, number of fruits plant-1 ${ }^{-1}$ fruit weight and yields were very low compared to other treatments.

\section{Conclusion}

The use of jatropha seedcake or its mixture with either chicken manure or kraal manure in tomato production is considered desirable. The use of jatropha seedcake or its mixture with either chicken manure or kraal manure as organic manure will improve soil $\mathrm{pH}$, soil organic matter status, nutrients availability, bulk density, growth and increase crop yield. However, further studies will be required to be undertaken to evaluate the effects of jatropha seedcake, chicken and kraal manures on the nutritive value content of tomato fruits at the same application rate.

\section{References}

Ahmad, R., Jilani, G., Arshad, M., Zahir, ZA. and Khalid, A. 2007. Bio-conversion of organic wastes for their recycling in agriculture: An overview of perspectives and prospects. Ann. Microbiol. 57(4): 471-479. 
Anburani, A. and Manivannan, K. 2002. Effect of integrated nutrient management on grouth in brinjal. South Indian Hort. 50(4-6): 377386.

Arancon, N.Q., Edwards, C.I. and Bierman, P. 2006. Influences of vermin-composts on field strawberries: 2. Effects on soil microbiological and chemical properties. Bioresour. Technol. 97: 831-840.

Bertand, H.C. and Cleyetmarel, J.C. 2008. Stimulation on the ionic transport system in tomato plants. Can. J. Microbial. 66: 922930.

Bray, P.H. and Kurtz, L.T. 1945. Determination of total organic and available forms of phosphorus in soils. Soil Sci. 59 (1): 39-46.

Bremner, J.M. and Mulvancy, C.S. 1982. Nitrogen-Total. In: Page, A.L et al. (Eds,), Methods of soil analysis Part 2, Agron.

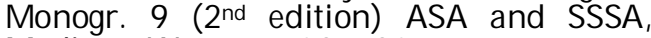
Madison, Wsc. pp. 403- 430.

Cano-Asseleih, L.N., Plumbly, R.A. and Hylands, P.J. 1989. Purification and partial characterization of the hemagglutinin from seeds of Jatropha curcas. J. Food Biochem. 13: $1-20$.

Chaturvedi, S. and Kumar, A. 2012. Bio-diesel waste as tailored organic fertilizer for improving yields and nutritive values of Lycopercicum esculatum (tomato) crop. J. Soil Sci. Plant Nutr. 12 (4): 801-810.

Chaturvedi, S., Chel. A., Satya, S. and Kaushik, G. 2008a. Viable tailored organic fertilizer alternatives from waste produced by BioDiesel extraction process. An addition in the value chain. ASME $2^{\text {nd }}$ International conference on energy sustainability, Florida. USA. pp. 233-244.

Chaturvedi, S., Singh, B., Nain, L., Khare, S.K. Pandey, A.K. and Satya, S. 2010. Evaluation of hydrolytic enzymes in bio-augmented compost of J atropha cake under aerobic and partial anaerobic conditions. Ann Micro. 60: 685-691.

Chaturvedi, S., Upreti, D.K., Tandon, D.K. Sharma, A. and Dixit, A. 2008b. Bio-waste from Tobacco industry as tailored organic fertilizer for improving yields and nutritional values of tomato crop. J. Environ. Biol. 29 (5): 759-763.

de Gruijter, J.J. 2002. Methods of Soil Analysis, Sampling. In: J.H. Dane and G.C. Topp, Eds. Part 4-Physical Methods. Soil Science Society of America, Inc., Madison, WI. pp. 45- 79.

Jayasingh, M. 2003. The use of Bio-diesel by the Indian Railways. Proceedings of the National Workshop 5-8 August, Pune. India.

Li, C.Y., Devappa, R.K., Liu, J.X., Lv, J.M., Makkar, H.P.S. and Becker, K. 2010. Toxicity of Jatropha curcas phorbol esters in mice. Food Chem. Toxicol. 48: 620-625.

Little, T.M and Hills, F.J. 1978. Agricultural experimentation, design and analysis. John Wiley and Hoboken, New Jersey, USA. p. 542.
Lombin, I.G., Adepet, I.A. and Ayotade, A. 1991. Complementary use of organic manures and inorganic fertilizer in arable production. Proceedings of National Organic Fertilizer Seminar held at Durbar Hotel, Kaduna, Nigeria. p. 146.

Marinari, S., Masciandaro, G., Ceccanti, B. and Grego, S. 2000. Influence of organic and mineral fertilizers on soil biological and physical properties. Bio-resource Tech. 72 (1): 9-17.

Martínez-Herrera, J., Siddhuraju, P., Francis, G. Dávila-Ortíz, G. and Becker, K. 2006. Chemical composition, toxic/antimetabolic constituents, and effects of different treatments on their levels, in four provenances of Jatropha curcas L. from Mexico. Food Chem. 96: 80-89.

Mbah, C.N., Mbagwu, J.S.C., Onyia, V.N. and Anikwe, M.A.N. 2004. Effect of application of bio-fertilizers on soil densification, total porosity, aggregate stability and maize grain yield in a dystricleptosol at Abakaliki. Nigeria J. Sci. Tech. 10: 74-85.

Mingochi, D.S. and Luchen, S.W.S. 2000. Improved vegetable production practice for smallholder farmers in Zambia. A reference manual for field extension workers. Smallholder Irrigation and Water Use Programme. Utf/zam/ 056/zam, $\mathrm{mtf} / \mathrm{int} / 001 / \mathrm{fta}$. Field Document No. 1.

Ministry of Agriculture. 1991. Soil Survey Section, National Soil map of Zambia.

Mwiinga, M.N. 2009. An assessment of tomato price variability in Lusaka and its effects on smallholder farmers. Agriculture and Food Resource Economics, Michigan State University. p. 53.

Neilsen, G.H., Hogue, E.J., Neilsen, D. and Zebarth, G.H. 1998. Evaluation of organic wastes as soil amendments for cultivation of carrots and chard on irrigated sandy soils. Can. J. Soil Sci. 78: 217- 225.

Olk, D.C. and Cassman, K.G. 1993. Reduction of potassium fixation by organic matter in vermiculitic soils. Soil Organic Matter Dynamics and Sustainability of Tropical Agriculture. pp. 307-315.

Perkin-Elmer. 1994. Analytical Methods for Atomic Absorption Spectroscopy. The Perkin Elmer Corporation, USA.

Singh, G., Sctharaman S.P. and Chockshi, S.N. 1996. A study into the production and marketing of Jatropha curcas. Centre for management in Agriculture. Indian Institute of Management, Ahemedabad, India. 33: 159-162.

Stolte, J., Veerman, G.J. and Wopereis, M.C.S. 1992 .Manual of Soil Physical Measurements Version 2.0 tech Doc. 2. DLO. Win and Staring Centre, Wageningen. The Netherlands. p. 49.

Walkley, A. and Black, I.A. 1934. An examination of Degtjareff method for determining soil organic matter and a proposed modification of the chromic acid titration method. Soil Sci. 37: 29-37. 